Relato de Caso / Case Report

\title{
Cold agglutinin disease (CAD)with autoimmune haemolytic anaemia: A case report of a coronary artery disease patient
}

\author{
Doença por aglutininas a frio (DAC) com anemia hemolítica auto-imune: relato de caso de um \\ coronariopata
}

\author{
Leandro A. Barbosa \\ Monica S. Rocha ${ }^{2}$ \\ Agatha P. F. Maia ${ }^{3}$ \\ Erica T. S. Leite \\ Angela P. Carrano 5 \\ Edimilson A. Silva
}

\begin{abstract}
Cold agglutinin disease (CAD) with autoimmune haemolytic anemia is characterized by the production of harmful cold autoantibodies associated with increased red cell destruction during exposure to cold. The treatment of CAD is very difficult and a great effort is required to obtain therapeutic success. Cyclophosphamide is a potent immunosuppressive agent which is widely used in all bone marrow transplantation conditioning regimens for patients with acquired severe aplastic anemia. In this report, we describe the case of a coronary artery disease patient with severe $C A D$, but without lymphoproliferative disease, in which general measures and immunosuppressive therapies were adopted, there by avoiding blood transfusions. Rev. bras. hematol. hemoter. 2008;30(1):78-80.
\end{abstract}

Key words: Cold agglutinin disease; coronary artery disease; cyclophosphamide;.

\section{Introduction}

Cold agglutinin disease (CAD) with autoimmune haemolytic anaemia is characterized by the production of harmful cold autoantibodies associated with increased red cell destruction during exposure to cold. Two clinical syndromes may be distinguished, one chronic and other transient. The former is generally found in association with neoplasy; while the latter usually occur following infectious diseases. ${ }^{1}$ Cold agglutinins cause agglutination of erythrocytes with the affinity increasing with the decrease of temperature. ${ }^{2}$ As a consequence of the haemagglutination, most patients experience pallor, Acrocyanosis and Raynaud's phenomenom, during slight or moderate exposure to cold.$^{3}$ All patients have cold-induced haemolysis caused by concomitant complement activation during cold agglutinins binding. ${ }^{4}$ Primary CAD is an idiopathic form of the disease, and nearly all patients with secondary CAD have a limphoproliferative bone marrow disease, in which monoclonal cold agglutinins are produced directly by the neoplastic B cells. ${ }^{5}$

The treatment of CAD is very difficult, and a great effort is required to obtain therapeutic success. Corticosteroids are almost useless in the treatment of CAD, and so treatments include intravenous immunoglobulin, danazol, ${ }^{6}$ and a variety of immunomodulating agents including cyclophosphamide, azathioprine, cyclosporine, and vincristine. ${ }^{7}$

Cyclophosphamide is a potent immunosuppressive agent which is widely used in all bone marrow transplantation conditioning regimens for patients with

${ }^{1}$ Farmacêutico bioquímico com especiliazação em Biologia Celular.

${ }^{2}$ Bióloga com especialização em Hematologia.

${ }^{3}$ Bióloga.

${ }^{4}$ Médica(o) com especialização em Hematologia e Hemoterapia.

${ }^{5}$ Médica com especialização em Genética e Hemoterapia.

1,2,3,4,5 CMT - Centro de Medicina Transfusional, Hospital Pró-Cardíaco, Rio de Janeiro, RJ, Brazil.

${ }^{1}$ LERPA - Laboratório de Estrutura e Regulação de Proteínas e ATPases, UFRJ, Rio de Janeiro, RJ, Brazil..

Correspondence: Edmilson A. Silva

Centro de Medicina Transfusional (CMT)/ Pró-Cardíaco Pronto Socorro Cardiológico S/A

Rua Dona Mariana, 219

22280-020 - Botafogo - Rio de Janeiro-RJ - Brasil

E-mail: edimass@terra.com.br 
acquired severe aplastic anemia. ${ }^{8}$ Cyclophosphamide produces interstrand and intrastrand DNA cross-linking, the cytotoxic result of the drug. This drug is highly immunosuppressive but not myeloablative, allowing endogenous haemopoietic stem cells to reconstitute haemopoiesis. ${ }^{9}$ Furthermore, higher-doses of cyclophosphamide have been used in the treatment of refractory autoimmune hemolytic anemia. ${ }^{10,11,12}$

In this report, we describe a case of a coronary artery disease patient with severe CAD, but without limphoproliferative disease, in which general measures and immunossupresive therapies were adopted, avoiding haemotransfusions.

\section{Case Report}

A 79 years-old man attended at our hospital presenting weakness, a long duration heart disease and a diagnosis of urinary infection in May 2004. Immediately before his hospitalization he was treated with cephalexin and pennicillin, and routinely he took diltiazem, aspirin, alfuzosin hydrochloride, mononitrate isossorbide, simvastatin, zopiclone and omeprazole.

The medical history included myocardium revascularization on 1986 and 1998, and angioplasty interventions in 2000 and 2002. During the myocardium revascularization surgery of in 1998, he received some blood units and suffered from a not very well characterized transfusion reaction described at that time as fever and urticaria.

On his admission in May 2004, laboratory tests showed a haemoglobin $(\mathrm{Hb})$ level of $8.0 \mathrm{~g} / \mathrm{dL}$, haematocrit $(\mathrm{Ht})$ of $21.3 \%$, and a reticulocyte count (Ret) of $4.9 \times 10^{9} / \mathrm{L}$. No disorders of his white blood cells and platelet counts were observed, but heavy spontaneous agglutination was noted immediately during blood collection. The blood smear demonstrated the features of anisopoikilocytosis, hypochromia, spherocytes, polychromasia, orthocromatic eritroblast cells and red cell agglutinates.

The clinical and laboratorial features were suggestive of haemolysis, with pallor and subicteric mucous membranes associated with an increased serum lactate dehydrogenase level (LDH, 1007 IU/ L; normal 100-450 IU/L), a high level of indirect bilirubin concentration (I-bil, $2.4 \mathrm{mg} / \mathrm{dL}$; normal 0.1$0.6 \mathrm{mg} / \mathrm{dL}$ ), and a decreased level of the serum haptoglobin (28 mg/L; normal 1030-3410 mg/L). Immunohematological studies were performed using previously warmed blood because of the spontaneous blood agglutination and the results obtained were: group $\mathrm{A}$, Rh positive, direct antiglobulin test (DAT) positive for C3d $(+++/ 4+)$, but negative for IgM, IgG, IgA and C3c; eluate negative. Agglutination during crossmatching with blood units was observed but no alloantibodies were detected by indirect antiglobulin test. No serum reactivity was observed for red blood cells coated with cefalexin. Serology for mycoplasma pneumoniae, mononucleosis, human immunodeficiency virus (HIV), hepatitis A, B, and C were all negative. Quantitative immunoglobulin levels were: IgG 930 mg/dL (normal 700-1600 mg/dL); IgA 143 mg/dL (normal 70-400 mg/dL); IgM 175 mg/ dL (normal 40-230 mg/dL). Clinical examinations did not detect organomegalias nor lymphoadenopathy, which was not seen on chest and abdominal images either.

The day after his admission, empirical administration of erythropoietin ( $40.000 \mathrm{UI} /$ week), folic acid ( $5 \mathrm{mg} /$ day), oral vitamin B12 (500 UI/day) and ferrous sulfate (900mg/day) was initiated. He was initially treated with oral prednisone (1 mg/Kg/day), with no improvement in his haemoglobin level even after 15 days. For this reason, immunosuppression was modified by adding cyclophosphamide at $200 \mathrm{mg} /$ day. This treatment was maintained for six months.

After this therapeutic approach, we observed an increase in haemoglobil levels from 8.0 to $10 \mathrm{~g} / \mathrm{dL}$, with no RBC transfusions being necessary during all his hospitalization over a period of two months. However, until March 2006 some abnormal laboratorial data still remained such as the in vitro spontaneous haemagglutination, hemoglobin level of 10-11 g/dL, DAT positive, LDH and increased indirect billirubin concentration.

\section{Discussion}

Patients with CAD associated with autoimmune haemolytic anaemia plus infections often have only a short transient syndromes where cold haemagglutinins are polyclonal, requiring no specific therapy. However, patients who have lymphomas and cold agglutination may display a more chronic course, thus specific treatment is often necessary. ${ }^{13}$ Therapeutic approaches often successful in warm-type AIH, such as corticosteroids, are usually ineffective with CAD, increasing the demand for an alternative treatment. Rituximab is a new drug which is effective against primary CAD, but generally used in patients with lymphoproliferative diseases. ${ }^{5,14,15}$ Because of high cost of rituximab and its properties in diseases, other therapeutic drug need to be evaluated in CAD.

Cyclophosphamide has been used in the treatment of CAD with some success. Because of its immunosuppressive properties, it is a good choice to use in CAD, without causing severe side effects. ${ }^{10,11,16}$

In our case, the patient did not present with lymphoadenopathy or organomegalias, but he consistently exhibited CAD. Cyclophosphamide treatment proved to be only partially effective. His haemoglobin levels increased from 8.0 to $11.0 \mathrm{~g} / \mathrm{dL}$; despite this increase, after six months of treatment, there was no improvement in his DAT or spontaneous haemoagglutination. It is important to notice that the use of erythropoietin, folic acid, vitamin B12 and ferrous sulfate in all this period added a therapeutic 
contribution to avoid blood transfusions maintain a minimal acceptable level of haemoglobin in a coronary artery disease patient.

The management of CAD is problematic for blood banks, particularly in relation to those patients that require special care of haemoglobin levels: the elderly and coronary artery patients. On the other hand, CAD can obscure the detection of alloantibodies, contribuiting to a major complexity in blood banks with the possibility of future blood transfusions. There have been reports in which exacerbation of hemolytic anemia required multiple incompatible transfusions in the specific case of heart disease patients. ${ }^{17}$ Thus an effort should be made with a multidisciplinary team to reasonably evaluate the conditions of sick patients. The difficulty in deciding to transfuse an incompatible unit may lead to avoiding transfusion where transfusion is needed, in cases of inappropriate therapeutic responses.

This case illustrates very well a chronic course of CAD in spite of a lymphoproliferative bone marrow disease not being detected until now. High dose treatments with cyclophosphamide could be an alternative therapeutic choice for CAD, associated with haemopoiesis-stimulanting drugs, limiting the risk of blood component consumption.

\section{Resumo}

A doença por aglutininas a frio (CAD) cursando com anemia hemolítica auto-imune (AHAI) é decorrente da produção de autoanticorpos que reagem muito bem a baixas temperaturas, dirigidos contra hemácias autólogas. A habilidade desses anticorpos em destruir as hemácias encontra-se diretamente relacionada à sua capacidade em fixar complemento durante a exposição do paciente a baixas temperaturas. A AHAI por anticorpos frios pode ser idiopática - ausência de doença de base - ou secundária, geralmente associada a desordens linfoproliferativas de células $B$ ou determinados processos infecciosos. A hemólise é intravascular, através de aglutininas da classe IgM, com teste direto da antiglobulina humana positivo para complemento. O tratamento da CAD é difícil, exigindo um esforço contínuo, necessário para se obter sucesso terapêutico. A ciclofosfamida é um agente imunossupressor potente, amplamente utilizado em transplantes de medula óssea, particularmente nos portadores de anemia aplástica. Descrevemos o caso de um coronariopata portador de CAD severa, cuja exploração diagnóstica excluiu doença linfoproliferativa. Adotamos medidas gerais de suporte e terapia imunossupressora, coibindo o uso de hemotransfusões. Rev. bras. hematol. hemoter. 2008;30(1):78-80.

Palavras-chave: Doença por aglutininas a frio; anemia hemolítica; auto-imune; anticorpo frio; ciclofosfamida; doença coronariana.

\section{References}

1. Berentsen S, Ulvestad E, Langhorlm R, Beiske K, Hjorth-Hansen H, Glanima W et al. Primary Chronic cold agglutinin disease: a population based clinical study of 86 patients. Haematologica. 2006;91:460-5.
2. Dacie SJ. The immune haemolytic anaemias: a century of exciting progress in understanding. Br J Haematol. 2001;114:770-85.

3. Berentsen S, Bo K, Shammas FV, Myking AO, Ulvestad E. Chronic cold agglutinin disease of the "idiopathic" type is a premalignant or low-grade malignant lymphoproliferative disease. APMIS. 1997; 105:354-62.

4. Kirschfink M, Knoblauch K, Roelcke D. Activation of complement by cold agglutinins. Infusionsther Transfusionsmed. 1994;21:405-9.

5. Berentsen S, Tjonnfjord GE, Brudevold R, Gjertsen BT, Langholm $\mathrm{R}$, Lokkevik E et al. Favourable response to therapy with the anti-CD20 monoclonal antibody rituximab in primary chronic cold agglutinin disease. Br J Haematol. 2001;115:79-83.

6. Ahn YS, Harrington WJ, Mylvaganam R, Ayub J, Pall LM. Danazol therapy for autoimmune hemolytic anemia. Ann Intern Med. 1985; 102:298-301.

7. Petz LD. Drug-induced immunehaemolytic anaemia. Clin Haematol. 1980;9:455-82.

8. Brodsky RA, Sensenbrenner L, Jones RJ. Complete remission in severe aplastic anemia after high-dose cyclophosphamide without bone marrow transplantation. Blood. 1996;87:491-4.

9. Brodsky RA, Jones RJ. Aplastic anaemia. Lancet. 2005; 365: 1647-56.

10. Moyo VM, Smith D, Brodsky I, Crilley P, Jones RJ, Brodsky RA. High-dose cyclophosphamide for refractory autoimmune hemolytic anemia. Blood. 2002;100:704-6.

11. Nakagawa M, Miyagishima T, Kamata T, Arai S, Miura Y, Onishi $\mathrm{S}$ et al. Refractory idiopathic cold agglutinin disease succefully treated with intermittent high-dose cyclophosphamide. Rinsho Ketsueki. 2001;42:713-5.

12. Budmiger H, Rhyner K, Siegenthaler-Zuber G, Bollinger A. Idiopathic cold agglutinin disease. Clinical aspects, therapy and course in 6 patients. Schweiz Med Wochenschr. 1988;118:52-7.

13. Lee JH, Lee JH, Shin YR, Lee JS, Kim WK, Chi HS et al. Spontaneous remission of aplastic anemia: a retrospective analysis. Haematologica. 2001; 86:928-33.

14. Mori A, Tamaru J, Sumi H, Kondo H. Beneficial effects of rituximab on primary cold agglutinin disease refractory to conventional therapy. Eur J Haematol. 2002;68:243-5.

15. Robak T. Monoclonal antibodies in the treatment of autoimmune cytopenias. Eur J Haematol. 2004;72:79-88.

16. Budmiger H, Rhyner K, Siegenthaler-Zuber G, Bollinger A. Idiopathic cold agglutinin disease. Clinical aspects, therapy and course in 6 patients. Schweiz Med Wochenschr. 1988;118:52-7.

17. Svensson AM, Bushor S, Fung MK. Case report: exacerbation of hemolytic anemia requiring multiple incompatible RBC transfusions. Immunohematol. 2004;20:177-83.

Avaliação: Editor e dois revisores externos

Conflito de interesse: não declarado

Recebido: 20/11/2006

Aceito após modificações: 26/04/2007 